\title{
Efficiency of Testosterone Administration on the Performance of Day Old Chick (DOC) Layer: Cockscomb Size, T3/T4 Ratio, and Histopathological Description of Bursa Fabricius
}

\author{
Rizki Fitrawan Yuneldi ${ }^{1}$, Claude Mona Airin ${ }^{2}$, Hendry TSSG Saragih ${ }^{3}$, Pudji \\ Astuti $^{2 *}$ \\ ${ }^{I}$ Veterinary Science Doctoral Program, Faculty of Veterinary Medicine Universitas Gadjah Mada Yogyakarta, \\ Indonesia \\ ${ }^{2}$ Department of Physiology, Faculty of Veterinary Medicine, Universitas Gadjah Mada Yogyakarta, Indonesia \\ ${ }^{3}$ Laboratory of Animal Structure and Development, Faculty of Biology, Universitas Gadjah Mada Yogyakarta, \\ Indonesia \\ ${ }^{*}$ Corresponding author. Email: pastuti2@ugm.ac.id
}

\begin{abstract}
This study aimed to evaluate the efficiency of single and continuous testosterone injection against cockscomb size, T3/T4 ratio, and histopathological features of the bursa of Fabricius in the male layers. Sixty DOC layers were divided into 3 groups namely control $(\mathrm{C})$, single testosterone injection with a dose of $3 \mathrm{mg} / \mathrm{day}\left(\mathrm{T}_{\mathrm{O}}\right.$ ), and continues testosterone injection induced for 35 days $\left(\mathrm{T}_{\mathrm{C}}\right)$. One $\mathrm{mL}$ of blood was collected through the brachial vein, cockscomb measurements were performed serially every week for 5 weeks, while the bursa of Fabricius organ was carried out subsequently after the animal was sacrificed. Analysis of thyroid hormones was performed using ELISA, while the histopathological features were performed by HE staining. The results showed that cockscomb size was $\mathrm{C}:(6.29 \pm 1.62), \mathrm{T}_{\mathrm{O}}:(7.79 \pm 0.21)$, and $\mathrm{T}_{\mathrm{C}}$ : $(8.64 \pm 1.58) \mathrm{cm}^{2}$. However, there was no difference between $\mathrm{T}_{\mathrm{O}}$ and $\mathrm{T}_{\mathrm{C}}$ at week $5(\mathrm{P}>0.05)$. There was a significant decrease of the T3/T4 ratio at week 3, control: 3.24 $\pm 0.18 ; \mathrm{T}_{\mathrm{O}}: 3.76 \pm 0.39$; and $\mathrm{T}_{\mathrm{C}}: 2.44 \pm 0.14$. At the age of 35 days, crystals had been formed in the bursa of Fabricius in group $\mathrm{T}_{\mathrm{O}}$ and $\mathrm{T}_{\mathrm{C}}$. In conclusion, testosterone injection affects cockscomb size, T3/T4 ratio, and accelerates degeneration of the bursa of Fabricius. Furthermore, the administration of a single dose of testosterone injection is more efficient than the continuous one.
\end{abstract}

Keywords: Rooster layer, cockscomb size, ratio T3/T4, bursa fabricius

\section{INTRODUCTION}

The performance of roosters such as growth, sexual maturity, cockscomb size, muscle strength, the beauty of the rooster sounds to the color of the feathers is greatly influenced by testosterone hormone. Unfortunately, the use of testosterone continuously in small doses has a negative effect. Yuneldi et al. [1] reported that testosterone administration significantly affects the lenght of cockscomb. Based on the growth rate, the significant increase of body weight occurred in broilers aged 21 and 24 days which were given testosterone at a dose of $2 \mathrm{mg}$ per head [2] Furthermore, the administration of testosterone will increase body metabolism in line with the increase of chicken body weight, the decrease of T3 levels, and fluctuating T4 levels as reported by Yuneldi et al. [3]. One indicator of maturity levels in chicks is demonstrated from the degeneration of the bursa of Fabricius [4]. Previous researchers reported that testosterone suppress the function of $\mathrm{B}$ cell lymphocytes (cells producing antibodies) and $\mathrm{T}$ cell lymphocytes (regulators of cell-mediated immunity) in vitro [5].

The aim of this study was to evaluate the administration of testosterone in a single dose and 
continue toward the cockscomb size, T3 / T4 ratio, and histopathological features of the bursa of fabricius.

\section{MATERIALS AND METHODS}

This study used 60 DOC of male layer chickens [Gallus gallus gallus (Linnaeus 1758)] with a weight of \pm 50 grams. They were randomly divided into 3 treatment groups, the control group (C) was injected with physiological $\mathrm{NaCl}), \mathrm{T}_{\mathrm{O}}$ was injected with a single dose of testosterone $(0.1 \mathrm{~mL})$, and $\mathrm{T}_{\mathrm{C}}$ was given daily testosterone injection at a dose of $3 \mathrm{mg} /$ day $(0.1 \mathrm{~mL})$ subcutaneously for 35 days [2, 6]. The variables analyzed were the size of the cockscomb, the ratio of $\mathrm{T} 3 / \mathrm{T} 4$, and the histopathological features of the bursa of Fabricius.

Blood sampling and comb measurement were performed serially, starting from week 1 to week 5 . Blood was collected through the brachial vein for $1 \mathrm{~mL}$. Serum was separated by centrifugation at $3000 \mathrm{rpm}$ for 15 minutes then stored at $-20^{\circ} \mathrm{C}$. Analysis of T3 and T4 hormones was carried out using the Enzyme Link Immunosorbent Assay (ELISA) method. Cockscomb measurement was done by measuring the comb length and width (height) of the comb. Measurements were conducted on the longest or widest area as much as 3 times, then the mean value was determined. Bursa of Fabricius was collected shortly after the chicken was sacrificed, followed by histological preparation using HE staining method.

The data obtained were analyzed using several ways. The performance of cockscomb and histopathological features of bursa of Fabricius were performed descriptively, while the T3/T4 ratio and size of cockscomb were performed using one way ANOVA at a $95 \%$ confidence level with the help of software (SPSS version 15). In case there are significant differences, the test is continued to Tukey HSD. All procedures have been approved by the Ethical Clearance Commission of the Integrated Research and Testing Laboratory of Universitas Gadjah Mada (UGM) certificate number 00059/04/LPPT/XI/2019.

\section{RESULTS AND DISCUSSION}

\subsection{The Effect of Testosterone Injection on Cockscomb Size}

The results of cockscomb measurement and performance after treated with testosterone can be seen in Table 1 and Figure 1. It was clearly seen from the picture that the injection of testosterone affects significantly to the size and color of the cockscomb. The control group $(\mathrm{C})$ had smaller comb size and paler compared to groups $T_{O}$ and $T_{C}$. Group $T_{C}$ had the biggest cockscomb size with the brightest color and thickest cockscomb than groups To and C.
The statistical results showed that there were significant differences between the control group and the treatment groups, especially the group that was given testosterone continuously $(\mathrm{P}<0.05)$. This difference began at week 1 to week 5, whereas significant differences between the group injected with testosterone once and continued group occurred at weeks 2,3 , and $4(\mathrm{P}<0.05)$.
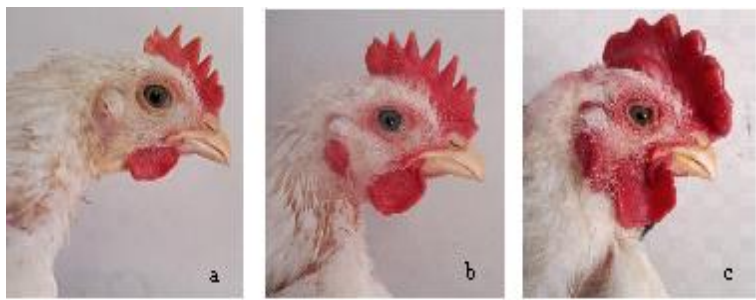

Figure 1 Cockscomb performance on control (a), $\mathrm{T}_{\mathrm{o}}$ (b), and $\mathrm{T}_{\mathrm{c}}$ (c) groups. It showed that testosterone significantly affects the size and color of the cockscomb. The administration of testosterone resulting in the increase of the cockscomb size and has a brighter color.

Testosterone implants can increase the level of testosterone, so as the color and size of the comb. However, this effect depends on the level of intrasexual competition. Moreover, it has a negative effect such as less physical quality and performance. In particular, testosterone implanted in birds increased testosterone levels and comb lenght, however decrease body condition. It happens in the populations where the intra-sexual competition was low [7]. Previous researchers stated that this poor body condition was marked by a decrease in testicular weight at week 3 as reported by Yuneldi et al. [1].

\subsection{The Effect of Testosterone Injection on T3/T4 Ratio}

Bain [8] explains that the thyroid hormone is very important for metabolism and growth both in humans and poultry; in young birds, it also supports oxygen consumption [9]. Yuneldi et al. [3] reported that the injection of testosterone further decreased T3 and T4 levels. In this study, similar results were found that the T3/T4 ratio decreased over time (Table 2 and Figure 2). However, on closer examination, it appears that the decrease in the T3/T4 ratio at week 3 was significantly decreased between studies $(\mathrm{P}<0.05)$. According to Andriyanto et al. [2], the growth of chickens was started in the first week, reaching maximum growth in the 3rd week, then it experienced a constant decline in growth. The decrease in the T3/T4 ratio in this study is predicted due to an increase in metabolism for growth. 
Moreover, Hanon et al. [10] reported that in poultry, T3 hypothalamic epidermal cells to stimulate the DIO2 stimulates the release of neuroendocrine $\mathrm{GnRH}$ at the enzyme until the conversion of T4 to T3 occurs. end of the eminence media. Therefore, TSH affects the

Table 1 The average size of cockscomb on male layer chicken after treated

\begin{tabular}{|l|c|c|c|c|c|}
\hline \multirow{2}{*}{\multicolumn{1}{c|}{ Treatment }} & \multicolumn{5}{|c|}{ Average \pm SD cockscomb size $\left(\mathrm{cm}^{2}\right)$ on week- } \\
\cline { 2 - 6 } & 1 & 2 & 3 & 4 & 5 \\
\hline Control & $0.21 \pm 0.10^{\mathrm{b}}$ & $0.41 \pm 0.18^{\mathrm{b}}$ & $1.14 \pm 0.12^{\mathrm{b}}$ & $1.94 \pm 0.91^{\mathrm{c}}$ & $6.29 \pm 1.62^{\mathrm{b}}$ \\
\hline T. Once (To) & $0.39 \pm 0.06^{\mathrm{a}}$ & $0.40 \pm 0.07^{\mathrm{b}}$ & $1.25 \pm 0.19^{\mathrm{b}}$ & $3.98 \pm 0.98^{\mathrm{b}}$ & $7.79 \pm 0.21^{\mathrm{ab}}$ \\
\hline T. Continues (TC) & $0.55 \pm 0.11^{\mathrm{a}}$ & $2.67 \pm 0.23^{\mathrm{a}}$ & $2.70 \pm 0.12^{\mathrm{a}}$ & $7.17 \pm 1.10^{\mathrm{a}}$ & $8.64 \pm 1.58^{\mathrm{a}}$ \\
\hline
\end{tabular}

${ }^{\mathrm{a}-\mathrm{d}}$ Different letters in the same row show significant difference $(\mathrm{P}<0.05)$.

Table 2 Profile of Ratio T3/T4 during the treatment

\begin{tabular}{|l|c|c|c|c|c|}
\hline \multirow{2}{*}{\multicolumn{1}{|c|}{ Treatment }} & \multicolumn{5}{|c|}{ Average \pm SD Ratio of T3/T4, Wage- } \\
\cline { 2 - 6 } & 1 & 2 & 3 & 4 & 5 \\
\hline Control & $4.97 \pm 0.33^{\mathrm{a}}$ & $4.35 \pm 0.26^{\mathrm{b}}$ & $3.24 \pm 0.18^{\mathrm{b}}$ & $2.70 \pm 0.58^{\mathrm{b}}$ & $1.58 \pm 0.12^{\mathrm{a}}$ \\
T.Once (To) & $2.62 \pm 0.55^{\mathrm{b}}$ & $6.33 \pm 0.73^{\mathrm{a}}$ & $3.76 \pm 0.39^{\mathrm{a}}$ & $3.68 \pm 0.71^{\mathrm{a}}$ & $1.76 \pm 0.56^{\mathrm{a}}$ \\
T.Continues (TC) & $4.86 \pm 0.56^{\mathrm{a}}$ & $4.17 \pm 0.12^{\mathrm{b}}$ & $2.44 \pm 0.14^{\mathrm{c}}$ & $2.71 \pm 0.31^{\mathrm{b}}$ & $1.64 \pm 0.25^{\mathrm{a}}$ \\
\hline
\end{tabular}

${ }^{a-d}$ Different letters in the same row show significant difference $(\mathrm{P}<0.05)$.

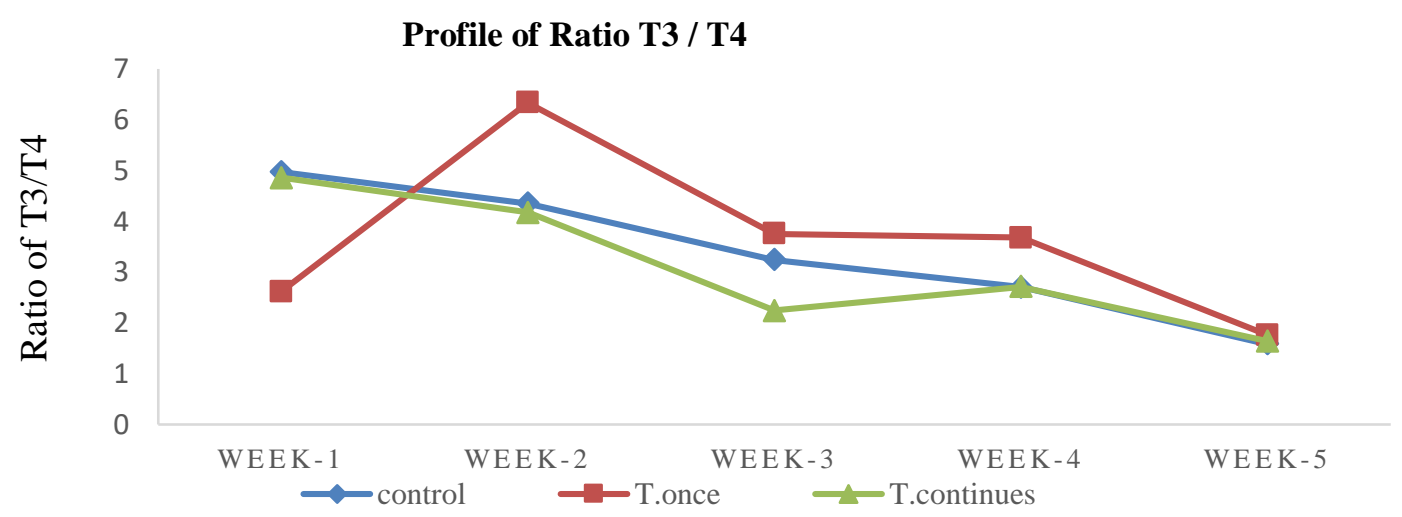

Figure 2 Ratio profile of T3/T4 on various treatments. The control group shows the decrease of T3/T4 level since week 1 until week 5, while othrs show fluctuative movement and ended by the fall of T3/T4 levels.

Testosterone can reduce fat mass and increase lean body mass. However, overall body weight did not show a significant change [11]. Elwahesh et al. [12] explained that the increase in body weight is strongly associated with a decrease of T3 levels. This decrease is related to the high metabolism required for body weight growth [13]. 


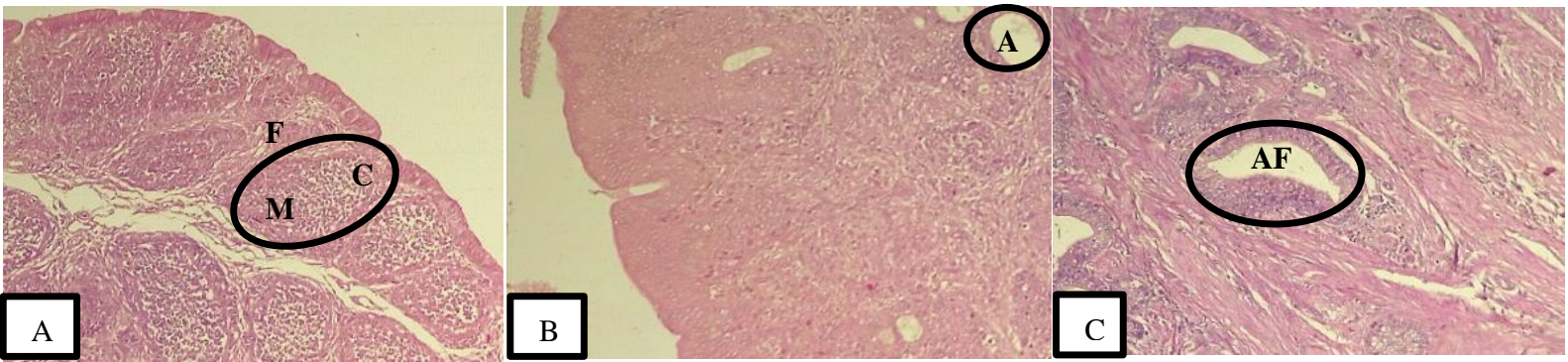

Figure 3 Histopathological features of bursa Fabricius on 35 days old layer. A: control group; B: To group, and $\mathrm{T}_{\mathrm{C}}$ group (lower). Bursa Fabricius in groups $T_{0}$ and $T_{c}$ has experienced degenerative growth which is characterized by cysts that are predicted due to testosterone administration. F: follicle; M: medulla; C: cortex; AF: atresia follicle.

\subsection{The Effect of Testosterone Injection on Bursa Fabricius}

The bursa of Fabricius is one of the lymphoid organs that only found in birds and functions as an immune system [14]. It was reported by Rohyati [15] that the development of the bursa of Fabricius will be inhibited by the presence of testosterone. In this study, it was shown that in the control group, the bursa of Fabricius follicle was still intact and developing, whereas in both treatment groups there was a degenerative development characterized by cysts (Figure 3). Based on Ayman et al. [16] bursa of Fabricius was still developing until it was 56 days old chickens.

Lupetti et al. [17] stated that giving testosterone propionate to chickens can reduce the bursa of Fabricius and cause cyst formation. Nagy and Olah [18] further added that chemical bursectomy can be done by dipping or injecting eggs with a testosterone solution. Hasnita et al. [19] added that in adult local chickens, number of follicles was getting decrease. Cyst formation can also be caused by a viral infection. As reported by Tabbu [4] that the bursa of Fabricius organs that experience degenerative changes in the form of cyst formation can be caused by a viral infection. As the development of the bursa of Fabricius is inhibited, it indicate that the administration of testosterone able to accelerate the maturity of layer chickens.

\section{CONCLUSION}

To conclude, testosterone injection affect cockscomb size, T3/T4 ratio, and accelerate degeneration of bursa of Fabricius. Furthermore, a sigle dose testosterone administration has the same effect as continuously testosterone administration. Thus, giving testosterone once is more efficient than that of continuously.

\section{ACKNOWLEDGMENTS}

This research was funded by 2020 RTA-UGM grants. Thank you in advance to the Research Directorate of UGM and drh. Rizal Aidi, M.Sc., who has assisted the research.

\section{REFERENCES}

[1] R.F. Yuneldi, C.M. Airin, T. Saragih, P. Astuti, Application of natural aromatase blocker towards the level of testosterone in rooster layer [Gallus gallus gallus (Linn., 1758)], (2020) 1-6.

[2] Andriyanto, A.S. Satyaningtijas, R. Yufiandri, R. Wulandari, V.M. Darwin, S.N.A. Siburi, Performa dan kecernaan pakan ayam broiler yang diberi hormon testosteron dengan dosis bertingkat, Acta Vet. Indones. 3(1) (2016) 29-37. DOI: https://doi.org/10.29244/avi.3.1.29-37.

[3] R.F. Yuneldi, C.M. Airin, H.T. Saragih, P. Astuti, Profile of thyroid hormone in male layer chickens given by testosterone, 2020, 1-7

[4] C.R. Tabbu, Atlas Berwarna Penyakit Unggas, Yogyakarta, UGM Press. Badan Penerbit dan Publikasi Universitas Gadjah Mada, 2018, 1-439

[5] M. Cunningham, G. Gilkeson, Estrogen receptors in immunity and autoimmunity, Clin. Rev. Allergy Immunol. 40(1) (2011) 66-73. DOI: https://doi.org/10.1007/s12016-010-8203-5.

[6] P. Astuti, C.M. Airin Sarmin S, et al., Effect of shell as natural testosterone boosters in Sprague Dawley rats. Vet. World, 12(10) (2019) 16771681.

DOI:https://dx.doi.org/10.14202\%2Fvetworld.20 19.1677-1681

[7] J. Martínez-Padilla, L. Pérez-Rodríguez, F. Mougeot, S. Ludwig, S. M. Redpath, Intra-sexual competition alters the relationship between testosterone and ornament expression in a wild territorial bird, Horm. Behav. 65(5) (2014) 435- 
444.

https://doi.org/10.1016/j.yhbeh.2014.03.012.

[8] J. Bain, Testosterone and the aging male: To treat or not to treat?, Maturitas 66(1) (2010) 16-22. DOI:https://doi.org/10.1016/j.maturitas.2010.01.0 09.

[9] S. Boersma, Managing rapid growth rate in broilers, World Poult. 17(8) (2001) 20-21.

[10] E.A. Hanon, G.A. Lincoln, Fustin J.M et al. Ancestral TSH Mechanism Signals Summer in a Photoperiodic Mammal, Curr. Biol,18(15) (2008) 1147-1152. DOI: https://doi.org/10.1016/ j.cub.2008.06.076

[11] F. Saad, A. Aversa, A.M. Isidori, L. Zafalon, M. Zitzmann, L. Gooren, Onset of effects of testosterone treatment and time span until maximum effects are achieved, Eur. J. Endocrinol. 165(5) (2011) 675-685.

[12] R.M. Elwahesh, K.M. Ben-Elhaj, M.M. Draid, Relationship between body weight performance and plasma thyroid hormones in broiler hens, Int. J. Med. Res. Prof. 2(6) (2016) 6-10.

[13] M. Ritchie, Neuroanatomy and physiology of the avian hypothalamic/pituitary axis: Clinical aspects, Vet. Clin. North Am. - Exot. Anim. Pract. 17(1) (2014) 13-22. DOI: http://dx.doi.org/10.1016/j.cvex.2013.09.005.
[14] I.R. Tizzard, Veterinary Immunology an Introduction, 3 ed. Philadelphia, 1987.

[15] N. Rohyati, Pengaruh pemberian probiotik B-mix dan infeksi Salmonella enteritidis terhadap gambaran mikroskopis bursa Fabrisius pada ayam broiler, Institut Pertanian Bogor, 2002.

[16] U. Ayman, R. Alam, S.K. Das, Age-related development and histomorphological observations of bursa of Fabricius in sonali chicken, 3(1) (2020) 20-28.

DOI: https://doi.org/10.5455/jabet.2020.d103.

[17] M. Lupetti, A. Dolfi, S. Michelucci, The behavior of bursal lymphoid follicle-associated cells after treatment with testosterone, Anat. Rec. 205(2) (1983) 177-183. DOI: https://doi.org/10.1002/ar.1092050208.

[18] N. Nagy, I. Oláh, Locally applied testosterone is a novel method to in fluence the development of the avian bursa of Fabricius, J. Immunol. Methods. 343(2) (2009) 97-102. DOI: http://dx.doi.org/10.1016/j.jim.2009.01.013.

[19] H. Hasnita, D. Masyitha, H. Budiman, Gambaran histologis bursa fabricius ayam kampung (Gallus gallus domesticus) pada umur berbeda, 01(3) (2017) 398-403. DOI: https://doi.org/10.21157/jim\%20vet..v1i3.3386. 